\title{
Non-linear curve adjustments widen biological interpretation of relative growth analyses of the clam Tivela mactroides (Bivalvia, Veneridae)
}

Alexander Turra Guilherme N Corte Antonia Cecília Z Amaral Leonardo Q Yokoyama Márcia R Denadai $^{2}$

3 Departamento de Ciências do Mar / Instituto Saúde e Sociedade, Universidade Federal de São Paulo, Santos, SP, Brazil

Corresponding Author: Alexander Turra

Email address: turra@usp.br

Evaluation of relative (allometric) growth provides useful information to understand the development of organisms, as well as to aid in the management of fishery-exploited species. Usually, relative growth analyses use classical models such as the linear equation or the power function (allometric equation). However, these methods do not consider discontinuities in growth and may mask important biological information. As an alternative to overcome poor results and misleading interpretations, recent studies have suggested the use of more complex models, such as non-linear regressions, in conjunction with a model selection approach. Here, we tested differences in the performance of diverse models (simple linear regression, power function, and polynomial models) to assess the relative growth of the trigonal clam Tivela mactroides, an important fishing resource along the South American coast. Regressions were employed to relate parameters of the shell (length $(L)$, width $(W)$, height $(H)$ and weight $(S W)$ ) among each other and with soft parts of the organism (dry weight (DW) and ash-free dry weight (ASDW)). Then, model selection was performed using the information theory and multi-model inference approach. The power function was more suitable to describe the relationships involving shell parameters and soft parts weight parameters (i.e. $L$ vs. $S W, D W$, and AFDW, and $S W$ vs. $D W$ ). However, it failed in unveiling changes in the morphometric relationships between shell parameters (i.e. $L$ vs. $W$ and $H$; $W$ vs. $H$ ) over time, which were better described by polynomial functions. Linear models, in turn, were not selected for any relationship. Overall, our results show that more complex models (in this study polynomial functions) can unveil changes in growth related to modifications in environmental features or physiology. Therefore, we suggest that classical and more complex models should be combined in future studies of allometric growth of molluscs. 
1 Non-linear curve adjustments widen biological interpretation of relative growth analysis of the 2 clam Tivela mactroides (Bivalvia, Veneridae)

3

4 Alexander Turra $^{1 *}$, Guilherme N. Corte ${ }^{1,2}$, A. Cecília Z. Amaral ${ }^{2}$, Leonardo Q. Yokoyama ${ }^{1,3}$, 5 Márcia R. Denadai ${ }^{2}$

6 'Departamento de Oceanografia Biológica, Instituto Oceanográfico, Universidade de São Paulo, São Paulo, SP, 7 Brazil

$8{ }^{2}$ Departamento de Biologia Animal, Instituto de Biologia, Universidade Estadual de Campinas, CP: 6109, CEP:

9 13083-970, Campinas, SP, Brazil

$10{ }^{3}$ Departamento de Ciências do Mar, Instituto Saúde e Sociedade, Universidade Federal de São Paulo, Santos, SP, 11 Brazil

$12{ }^{*}$ Email: turra@usp.br

13 Running head: Relative growth in Tivela mactroides

14 


\section{ABSTRACT}

17 Evaluation of relative (allometric) growth provides useful information to understand the

18 development of organisms, as well as to aid in the management of fishery-exploited species.

19 Usually, relative growth analyses use classical models such as the linear equation or the power

20 function (allometric equation). However, these methods do not consider discontinuities in growth

21 and may mask important biological information. As an alternative to overcome poor results and

22 misleading interpretations, recent studies have suggested the use of more complex models, such

23 as non-linear regressions, in conjunction with a model selection approach. Here, we tested

24 differences in the performance of diverse models (simple linear regression, power function, and

25 polynomial models) to assess the relative growth of the trigonal clam Tivela mactroides, an

26 important fishing resource along the South American coast. Regressions were employed to relate

27 parameters of the shell (length $(L)$, width $(W)$, height $(H)$ and weight $(S W))$ among each other and with soft parts of the organism (dry weight (DW) and ash-free dry weight $(A S D W)$ ). Then,

29 model selection was performed using the information theory and multi-model inference approach. The power function was more suitable to describe the relationships involving shell parameters and soft parts weight parameters (i.e. $L$ vs. $S W, D W$, and $A F D W$, and $S W$ vs. $D W$ ). However, it failed in unveiling changes in the morphometric relationships between shell parameters (i.e. $L$ vs. $W$ and $H$; $W$ vs. $H$ ) over time, which were better described by polynomial

34 functions. Linear models, in turn, were not selected for any relationship. Overall, our results 35 show that more complex models (in this study polynomial functions) can unveil changes in 36 growth related to modifications in environmental features or physiology. Therefore, we suggest

37 that classical and more complex models should be combined in future studies of allometric 38 growth of molluscs. 


\section{INTRODUCTION}

Relative or allometric growth analysis allows a detailed evaluation of the proportionality among the body parameters of individuals, and is useful to estimate the production and biomass of a population from a single parameter such as length or width (Rainer 1985; Urban \& Campos 1994; Vasconcelos et al. 2018). It also provides a better comprehension of modifications in life strategies of species unraveling important steps in their development (Katsanevakis et al. 2006; Rabaoui et al. 2007). Changes in growth rates are usually linked to changes in environmental features (e.g. food availability), physiology (e.g. gonad maturation and spawning periods), or biotic interactions (e.g. increase of competition or predation), and must be considered when evaluating morphological modifications during the ontogeny of the individuals (Rabaoui et al. 2007; Caill-Milly et al. 2014). The analysis of allometric growth is therefore an important tool to support exploitation and management of harvested species (e.g. improving the size-selectivity of fishing gears) (Vasconcelos et al. 2018), and essential for the proposal of effective measures to protect living resources (e.g., monitoring of stocks and limiting harvesting practices according to size-based analyses of communities) (Robinson et al. 2010).

Traditionally, allometric growth analyses are performed using the linear equation and power function (allometric equation) (e.g., Gaspar et al. 2001; 2002; MacCord \& Amaral 2005; Vasconcelos et al. 2018). While the former $(y=a+b x)$ corresponds to an equivalent increase in size of a body part y (dependent variable) and another body part x (independent variable; the reference dimension), the power function (allometric equation) determines the relationship between two parts of the body through an exponential equation $y=a x^{b}$, where $b$ is a measure of the constant difference in the growth rates of the body parts $\mathrm{x}$ and $\mathrm{y}$ (Katsanevakis et al. 2006). However, the allometric exponent b is not necessarily constant and may exhibit breakpoints (i.e. 
65 points of discontinuity in slope) for instance resulting from marked changes in the environment

66 or physiology (Katsanevakis et al. 2006). As an alternative to overcome poor and misleading

67 interpretation of results, more complex models that consider that nonlinearity and breakpoints

68 may exist in the relationship of body parts (e.g., polynomial functions such as quadratic or cubic models) have been recommended (Hendriks et al. 2012; Katsanevakis et al. 2006). Preferably, researchers should consider a set of pre-established models and use model selection methods, such as the information theory and multi-model inference approach (Burnham \& Anderson 2002b), to ascertain which better fits the data (Katsanevakis et al. 2006; Rabaoui et al. 2007). common for fishes, but much scarcer for benthic invertebrates (Vasconcelos et al. 2018). For bivalves, the growth and shape of the shell are normally influenced by both environmental (e.g., temperature, depth, currents, wave exposure, and sediment) and biological factors (predation, growth, and burrowing abilities) (see revision by Gaspar et al. 2002). Therefore, variation in these conditions may produce varying growth patterns of the shell and soft parts of the animals. An evaluation of the allometric growth of the bivalve Pinna nobilis, for example, registered significant variation in growth among five populations related to various environmental factors (Rabaoui et al. 2007). Marked changes in bivalve allometric growth are also expected to be associated with the maturity of individuals (i.e., the onset of reproduction), given that more energy is allocated to soft parts (mainly to the development and maturation of gonads) than to

84 shell deposition (Bayne \& Worrall 1980; Rabaoui et al. 2007). To better understand the development of key species and provide critical information for fisheries stock assessment and management, it is therefore essential that allometric growth studies are performed on a wider

87 diversity of organisms and use a more comprehensive set of statistical models. Only through this 
88 approach, growth variation among species, and between and within populations (i.e., spatial and 89 temporal comparisons) can be unveiled.

90 In this study, we tested whether different models are equally adequate to estimate the 91 allometric growth of the trigonal clam Tivela mactroides (Born, 1778), an important fishing

92 resource in the Southeastern American coast (Denadai et al. 2005; Turra et al. 2016).

93 Specifically, we compared the suitability of models traditionally used in allometric growth

94 analyses (i.e., linear and power function models) with more complex models (i.e., polynomial

95 functions), and investigated whether alternative models may lead to a better interpretation of the 96 data and provide additional biological information about this species.

2. MATERIALS AND METHODS

2.1. Model species

The trigonal clam T. mactroides is a widespread species found along the South America coast, from Colombia to southeastern Brazil (Turra et al. 2014). This bivalve occurs from the shallow subtidal to the upper intertidal zone (Denadai et al. 2005), and is a main feeding resource for several species of fishes, sea-stars, and crabs (Turra et al. 2015a). Moreover, T. mactroides is economically important and intensively exploited by fishermen and recreational harvesters in many parts of South America (Turra et al. 2016).

\subsection{Study area}

This work was performed at Caraguatatuba Bay, which is located in southeastern Brazil

109 (Fig. 1) and comprises several sandy beaches along a $16 \mathrm{~km}$ beach arch (Denadai et al. 2013).

110 Wave energy is moderate at Caraguatatuba Bay because of the shadowing effect of São 
111 Sebastião Island (Denadai et al 2005), but beach characteristics vary in a north-south orientation.

112 The southernmost part has a wide intertidal ultradissipative terrace $(800 \mathrm{~m})$ with well-sorted fine

113 sand. The northern part has a more heterogeneous slope with low tide dissipative terrace and fine

114 poorly sorted sand (Denadai et al. 2005, Turra et al. 2014). The mean seawater temperature in

115 Caraguatatuba Bay ranges from $19^{\circ} \mathrm{C}$ in winter to $26^{\circ} \mathrm{C}$ in summer (Corte et al. 2015). Salinity

116 is usually above 30 and significant variations only occur near the rivers that flow into the bay

117 (Amaral and Nallin 2011).

118

$119 \quad$ 2.3. Sampling and laboratory procedures

120 Field work was done following procedures described in Turra et al. (2015). Briefly, clams

121 were sampled monthly from January 2003 until October 2004 in two areas with high abundance

122 of T. mactroides (Denadai et al. 2005) (Fig. 1). The first southern area extended from Porto Novo

123 to Palmeiras; and the northern area from Indaiá to Centro beach (Fig. 1). Both areas had $2000 \mathrm{~m}$

124 length and sampling was performed in the intertidal and subtidal zone of each area following

125 different procedures.

126 In the intertidal zone of each area, sampling was performed at eight randomly sorted

127 transects from 200 possibilities (i.e. the linear $2000 \mathrm{~m}$ length divided into 10-m intervals). Six or

128 seven samples (squares of $0.5 \times 0.5 \mathrm{~m}$ ) were excavated to a depth of $10 \mathrm{~cm}$ at regular intervals in

129 each transect. The number of samples collected at each transect depended on their length. A total

130 of 120 samples $\left(30 \mathrm{~m}^{2}\right)$ were collected per month in the intertidal area.

131 In the subtidal zone, sampling was performed using a fishing boat at five different depths,

132 i.e., 400, 800, 1200, 1600 and $2000 \mathrm{~m}$, from mean low water (MLW, $0.0 \mathrm{~m}$ ). At each depth, one

133 50-m dredging was performed at three randomly sorted transects perpendicular to the coast. 
134 Thus, 30 samples were dredged per month (2 areas x 5 depths $\mathrm{x} 3$ transects). Samples were taken

135 using a rectangular dredge $(70 \times 25 \mathrm{~cm})$ with $3.0 \mathrm{~mm}$ internal mesh size.

136 The sediment sampled at both intertidal and subtidal zones was washed with seawater

137 over a 3.0-mm-mesh sieve, using buckets. Clams from both zones were collected, counted and

138 measured for shell length to the nearest $0.01 \mathrm{~mm}$ with a digital caliper to examine the population

139 dynamics of T. mactroides at the study area as reported in Turra et al. (2014). Almost all the

140 individuals were returned alive to the sea after the measurements; however, approximately five

141 individuals from each of the 37 size classes identified in this population (from 3.0 to $39.0 \mathrm{~mm} ; 1$

$142 \mathrm{~mm}$ intervals) where taken for morphometric analyses, totaling 187 individuals. These specimens

143 were maintained in clean, aerated seawater for $24 \mathrm{~h}$ to eliminate the feces. After this period, the

144 soft parts were separated from the shells and dried at $60^{\circ} \mathrm{C}$ to achieve a constant weight and

145 afterwards record the shell weight and the soft parts dry weight. Dry weight was used to avoid

146 discrepancy in the amount of water retained or fluctuation in soft-parts weight due to changes in

147 the physiological processes (Vasconcelos et al. 2008; 2018). Ash weight was obtained after

148 incinerating the dried soft parts in a muffle furnace at $550^{\circ} \mathrm{C}$ for $5 \mathrm{~h}$. The ash-free dry weight

149 (organic content) was calculated by subtracting the ash weight from the dry weight. Thus, all

150 individuals had the shell length $(L)$, height $(H)$, and width $(W)$ measured (Fig. 2), and the shell

151 weight $(S W)$, soft parts dry weight $(D W)$, and ash-free dry weight $(A F D W)$ recorded.

152

153

\subsection{Data analysis}

154 The allometric growth of T. mactroides was analyzed using models that relate the shell

155 length (independent variable) to the shell height, shell width, shell weight, soft parts dry weight,

156 and ash-free dry weight ( $L$ vs $H, W, S W, D W$ and $A F D W$ ). The relationships between shell width 
157 (independent variable) and shell height ( $W$ vs $H$ ), and between the soft parts dry weight

158 (independent variable) and the shell weight and ash-free dry weight were also evaluated ( $D W$ vs

$159 S W$ and $A F D W$ ).

160 We used five models for the comparisons (Table 1): (1) simple linear regression $(y=b x)$,

161 (2) second-order polynomial function $\left(y=b x+c x^{2}\right)$, (3) third-order polynomial function $(y=$

$\left.162 b x+c x^{2}+d x^{3}\right)$, (4) fourth-order polynomial function $\left(y=b x+c x^{2}+d x^{3}+e x^{4}\right)$, and (5) power function

163 (allometric equation, $y=a x^{b}$ ). The candidate models for allometric growth were fitted to raw

164 data and the fitted equations were compared based on the Kullback-Leibler (K-L) information

165 theory and multi-model inference (MMI) (Burnham \& Anderson 2002). The Kullback-Leibler

166 (K-L) information theory can be interpreted as the distance from the approximating model to

167 full reality, and minimization of $\mathrm{K}-\mathrm{L}$ distance is essential for model selection (Katsanevakis et

168 al. 2006). Multi-model inference, in turn, is a procedure where parameters are estimated from

169 several different models rather than from one a priori selected model (Burnham \& Anderson

170 2002).

171 We used the small-sample bias-corrected form of the Akaike Information Criteria, $A I C_{c}$

172 (Hurvich \& Tsai 1989) of the AIC (Burnham \& Anderson 2002a) for the model selection,

173 according to the equation:

174

$$
A I C_{c}=A I C+\frac{2 k(k+1)}{n-k-1}
$$

175 where $A I C$ is given by:

$$
A I C=n\left(\log \left(2 \pi \frac{R S S}{n}\right)+1\right)+2 k
$$

177 where $R S S$ is the residual sum of squares of the regression, $n$ is the number of observations, and $k$

178 is the number of estimated parameters of the regression plus 1 . The model with the smallest $A I C_{c}$ 
179 value $\left(A I C_{c, \text { min }}\right)$ was selected as the 'best' among the tested models. The $A I C_{c}$ differences

180 between adjusted functions, $\Delta_{i}=A I C_{c, i}-A I C_{c, \text { min }}$, were computed over all pairs of candidate

181 models. According to Burnham \& Anderson (2002), models with $\Delta_{i}<2$ have substantial support,

182 models with $4<\Delta_{i}<7$ have considerably less support, and models with $\Delta_{i}>10$ essentially have

183 no support and can be ignored. In the present work, we considered that all values of $\Delta_{i}<2$ have

184 substantial support for the model, and in the case of multiple models having $\Delta_{i}<2$ we opted for

185 the simplest model (principle of parsimony), i.e. the model with fewer estimated parameters.

\section{5. $\quad$ Field Study Permissions}

188 All activities complied with the license issued by the appropriate federal environmental 189 agency (Ministério do Meio Ambiente (MMA) - Instituto Chico Mendes de Conservação da Biodiversidade (ICMBio) No. 19887-1; acronyms for, in English: Ministry of the

191 Environment - Chico Mendes Biodiversity Conservation Institute)

\section{RESULTS}

High determination coeficients $\left(\mathrm{r}^{2}>0.842\right)$ were obtained in all models fitted to the relationships between the morphometric parameters of T. mactroides (Table 2). For most relationships, more than one model was suitable since they had values of $\Delta i \leq 2$ (Table 2 ). The

197 third-order polynomial suitably described all morphometric relationships excluding the $L / W$

198 relationship. Nevertheless, considering the parsimony principle, the traditional power function

199 was overall the most adequate model and better described five morphometric relationships

$200(L / S W, L / D W, L / A F D W, S W / D W$, and $D W / A F D W)$. The third-order polynomial model was the 
201 best descriptor for two relationships $(L / H$ and $W / H)$, whereas the fourth-order polynomial was 202 selected as the best descriptor of the relationships $L / W$.

203 The relative growth between shell length and height was approximately isometric up to $20420 \mathrm{~mm} \mathrm{~L}$; above this size, shell length increased faster compared to shell height (Fig. 3). The 205 relative growth between shell length and width was always positive allometric (i.e., length 206 increased faster), but this relationship was stronger after reaching maturity (approximately 20 $207 \mathrm{~mm}$ in L, Pietro 1980). The relationships between shell length and soft parts showed that the 208 increase in soft parts ( $D W$ and $A F D W$ ) was slow in young individuals (below $20 \mathrm{~mm} \mathrm{~L}$ );

209 followed by a rapid increase in soft parts weight was observed after reaching maturity. A similar 210 relationship was observed between shell length and shell weight. The allometric growth between 211 width and height oscillated during growth, mainly between 15 and $25 \mathrm{~mm}$ in shell width. The 212 shell weight increased continuously (practically linearly) with soft parts dry weight. Similar 213 relationship was established between ash-free dry weight and soft parts dry weight.

\section{DISCUSSION}

216 The usual approach when studying allometric growth in marine species is to a priori 217 adopt the classical linear or allometric model (power function), which may have implications in 218 the accuracy and precision of the estimated parameters (Katsanevakis et al. 2006; Rabaoui et al. 219 2007). When only these classical models are used, less informative conclusions may be reached 220 by smoothing the real growth pattern (Protopapas 2007; Rabaoui et al. 2007). In this study, we

221 used the information theory and multi-model inference approach (Burnham \& Anderson 2002a)

222 to compare the suitability of classical (i.e., linear and power function models) and more complex 223 models (i.e., polynomial functions) to describe the allometric growth of T. mactroides. Our 
224 results showed that classical models may adequately describe most morphometric relationships

225 of this species. However, their use alone may hide subtle changes in the allometric growth and

226 prevent a full understanding of growth patterns.

The power function (allometric equation) was the best model describing five of the eight morphometric relationships analyzed (mainly relationships involving the weight parameters such as shell weight, dry weight and ash-free dry weight). This function is commonly used in morphometric analyses of bivalves (e.g., Clasing et al. 1994; Urban \& Campos 1994; Gaspar et al. 2001; Lomovasky et al. 2005), but is normally considered the weakest adjustment for many morphometric relationships in some marine invertebrates (Katsanevakis 2007; Rabaoui et al. 2007; Garraffoni et al. 2010). A main drawback in the use of the power function is that it does not consider breakpoints (i.e., marked changes in the allometric growth) and may hide major indications of morphological variability among individuals of different sizes (Rabaoui et al. 2007). Our results show that the power function best characterized the allometric growth between shell parameters and soft tissues, indicating that shell and somatic parts of T. mactroides grow with a constant allometric exponent, whereas polynomial models better described relationships between shell parameters. Likewise, Trussel (2000) found that changes in shell morphology in Littorina snails were not related to soft tissue variations, and McKinney et al.

241 (2004) reported that allometric regression models best described changes in soft tissue content

242 with shell length for 10 different species, including the ribbed mussel Geukensia demisa, the blue 243 mussel Mytilus edulis, and the quahog Mercenaria mercenaria.

244 Several factors may influence the growth of soft tissue relative to shell parameters. Food 245 availability, for instance, can strongly affect growth, storage and utilization of body reserves; 246 thereby altering allometric relationships (McKinney et al. 2004). Similarly, temperature and 
247 salinity may alter metabolic rates and determine net growth efficiency in bivalve species

248 (Resgalla Jr. et al. 2007, Xiao et al. 2014). The constant allometric growth of shell measurements

249 and weighings of T. mactroides at Caraguatatuba Bay is likely related to constant food supply to

250 the clams due to the presence of three rivers (i.e., Santo Antônio, Lagoa and Juqueriquerê - Fig.

251 1) that flow directly into the bay and provide a large amount of suspended organic material

252 (Corte 2015; Turra et al. 2015b). The absence of marked fluctuation in seawater temperature and 253 salinity at the study area (Amaral and Nallin 2011, Corte et al. 2015) probably also contributes to 254 the constant growth of soft tissues.

255 Although the power function was more precise to describe the morphometric relationship

256 between shell parameters and somatic parts, it was not enough to unveil changes in the

257 morphometric relationships between shell parameters. By adjusting polynomial functions, we

258 were able to detect differences in morphometric relationships of shell parameters over the

259 lifespan of T. mactroides. Changes in bivalves morphometric relationships are usually related to

260 the maintenance of an area/volume ratio that is physiologically suitable for the prevailing

261 environmental conditions (Gaspar et al. 2002; Rhoads \& Pannella 1970). For instance, the shell

262 of the pill clam Pisidium subtruncatum (Malm 1855) change from a rounded and thin-shelled

263 form to an angular and thick-shelled form depending on the proportion of sand in the sediment

264 (Funk \& Reckendorfer 2008), which enables the individuals to burrow easier in coarse

265 sediments. Similar modifications have also been observed in species that change their habits

266 from active burrowing juveniles to sedentary and deeper burrowing adults (Statzner \& Holm

267 1982), such as the razor clam Ensis macha that shows an abrupt change in shell shape during

268 growth, from squarer to more elongated (Barón et al. 2004). This elongated form enables razor 
269 clams to avoid predators by burrowing deeper with low energy requirements (Trueman 1967;

270 Urban 1994).

271 Modifications in the allometric relationships between shell parameters of T. mactroides

272 seem related to habitat changes and maturity of individuals. We observed that shell width and

273 height had a reduction in their proportional growth in relation to shell length when individuals

274 reached a length between 15 and $25 \mathrm{~mm}$. This change is appropriate for the subtidal-intertidal

275 migration undertaken by this species (Denadai et al. 2005). The smallest individuals are usually

276 found in mud sediments in the subtidal level, where burrowing with a more-inflated shell is

277 easier. As individuals reach maturity, they passively migrate to firm intertidal sandy substrata

278 and their shell becomes longer and more compressed, potentially facilitating burrowing in this

279 type of sediment. Maturity is also a frequent cause of a distinct change in morphology, given that

280 more energy is allocated to the development of gonads than to shell growth (Bayne \& Worrall

281 1980; Katsanevakis et al. 2006).

282 Besides providing further information for understanding the life history of species, the

283 knowledge of allometric growth has implications for economic exploitation of fishing resources.

284 In bivalves, the morphometric relationships between shell size and soft parts can help defining an

285 optimum size for exploitation. For T. mactroides, the analyses of allometric growth indicate that

286 more energy is invested in shell growth during early phases of the life cycle, thereby increasing

287 the protection and survival of juveniles. Only after reaching maturity, a faster increase in somatic

288 tissues was recorded. Thus, harvesting of $T$. mactroides should preferably target individuals with

289 shell length between $25-30 \mathrm{~mm}$. This would ensure that individuals are already able to

290 reproduce, thus providing a better income to local harvesters since a higher meat yield ( ratio

291 meat weight/shell weight) would be achieved. 


\section{CONCLUSIONS}

294

Our results show that the classical power function is useful to evaluate the relative growth

295

296

297

298

299

300

301

302

303

304

305

306

307

308

309

310

311

312

313

314

315

316

317

318

319

320

321

of Tivela mactroides. Nevertheless, the use of this model alone may hide subtle changes in

morphology related to environmental or physiological processes such as habitat changes and

maturity of individuals. Only by applying more complex models, in the present case polynomial

models, we perceived subtle modifications in the allometric growth of T. mactroides. In this

regard, we reinforce the recommendation that allometric growth analyses should consider a set of

pre-established models including traditional and more complex models. Certainly, this would

improve allometric analyses and provide stronger and more informative conclusions.

\section{ACKNOWLEDGEMENTS}

We are grateful to all the staff who worked on the Biota / Fapesp Bentos-Marinho project

(Proc 1998 / 07090-3).

\section{REFERENCES}

Amaral ACZ, and Nallin SAH. 2011. Biodiversidade e ecossistemas bentônicos marinhos do Litoral Norte de São Paulo, Sudeste do Brasil. Campinas, SP: UNICAMP/IB, 573 p.

Arrieche D, and Prieto A. 2006. Population parameters of the trigonal tivela Tivela mactroides (Bivalvia: Veneridae) from Caicara Beach, Anzoátegui, Venezuela. Ciencias Marinas 32:285-296.

Barón PJ, Real LE, Ciocco NF, and Ré ME. 2004. Morphometry, growth and reproduction of an Atlantic population of the razor clam Ensis macha (Molina, 1782). 2004 68:7. 10.3989/scimar.2004.68n2211

Bayne BL, and Worrall CM. 1980. Growth and Production of Mussels Mytilus edulis from Two Populations. Marine Ecology Progress Series 3:317-328.

Burnham K, and Anderson DR. 2002a. Information and likelihood theory: a basis for model selection and inference. Model selection and multimodel inference: a practical information-theoretic approach 2:49-97. 
322

323

324

325

326

327

328

329

330

331

332

333

334

335

336

337

338

339

340

341

342

343

344

345

346

347

348

349

350

351

352

353

354

355

356

357

358

359

360

361

362

363

364

365
Burnham KP, and Anderson DR. 2002b. Model selection and multimodel inference : a practical information-theoretic approach. New York: Springer

Caill-Milly N, Bru N, Barranger M, Gallon L, and D'Amico F. 2014. Morphological Trends of Four Manila Clam Populations (Venerupis philippinarum) on the French Atlantic Coast: Identified Spatial Patterns and Their Relationship to Environmental Variability. Journal of Shellfish Research 33:355-372. 10.2983/035.033.0205

Clasing E, Brey T, Stead R, Navarro J, and Asencio G. 1994. Population dynamics of Venus antiqua (Bivalvia: Veneracea) in the Bahía de Yaldad, Isla de Chiloé, Southern Chile. Journal of Experimental Marine Biology and Ecology 177:171-186. https://doi.org/10.1016/0022-0981(94)90235-6

Corte GN. 2015. Reproductive cycle and parasitism in the clam Anomalocardia brasiliana (Bivalvia: Veneridae). Invertebrate Reproduction \& Development 59:66-80. 10.1080/07924259.2015.1007215

Denadai MR, Amaral ACZ, and Turra A. 2005. Along- and across-shore components of the spatial distribution of the clam Tivela mactroides (Born, 1778) (Bivalvia, Veneridae). Journal of Natural History 39:3275-3295. 10.1080/00222930500126156

Denadai MR, Santos FB, Bessa E, Fernandez WS, Lorca L, and Turra A. 2013. Population biology and diet of Pomadasys corvinaeforrnis (Perciformes: Pomadasyidae) in Caraguatatuba Bay, Southeastern Brazil. Revista de Biologia Tropical 61:1947-1954.

Funk A, and Reckendorfer W. 2008. Environmental Heterogeneity and Morphological Variability in Pisidium subtruncatum (Sphaeriidae, Bivalvia). International Review of Hydrobiology 93:188-199. 10.1002/iroh.200710969

Garraffoni ARS, Yokoyama LQ, and Amaral ACZ. 2010. Allometry and population structure of Nicolea uspiana (Polychaeta: Terebellidae). Journal of the Marine Biological Association of the United Kingdom 90:877-883. 10.1017/s0025315409991354

Gaspar MB, Santos MN, and Vasconcelos P. 2001. Weight-length relationships of 25 bivalve species (Mollusca: Bivalvia) from the Algarve coast (southern Portugal). Journal of the Marine Biological Association of the United Kingdom 81:805-807. $10.1017 / \mathrm{S} 0025315401004623$

Gaspar MB, Santos MN, Vasconcelos P, and Monteiro CC. 2002. Shell morphometric relationships of the most common bivalve species (Mollusca: Bivalvia) of the Algarve coast (southern Portugal). Hydrobiologia 477:73-80. 10.1023/a:1021009031717

Hendriks IE, Basso L, Deudero S, Cabanellas-Reboredo M, and Álvarez E. 2012. Relative Growth Rates of the Noble Pen Shell Pinna nobilis Throughout Ontogeny Around the Balearic Islands (Western Mediterranean, Spain). Journal of Shellfish Research 31:749756. 10.2983/035.031.0319

Hurvich CM, and Tsai C-L. 1989. Regression and time series model selection in small samples. Biometrika 76:297-307. 10.1093/biomet/76.2.297

Katsanevakis S. 2007. Growth and mortality rates of the fan mussel Pinna nobilis in Lake Vouliagmeni (Korinthiakos Gulf, Greece): a generalized additive modelling approach. Marine Biology 152:1319-1331. 10.1007/s00227-007-0781-2

Katsanevakis S, Thessalou-Legaki M, Karlou-Riga C, Lefkaditou E, Dimitriou E, and Verriopoulos G. 2006. Information-theory approach to allometric growth of marine organisms. Marine Biology 151:949-959. 10.1007/s00227-006-0529-4 
366

367

368

369

370

371

372

373

374

375

376

377

378

379

380

381

382

383

384

385

386

387

388

389

390

391

392

393

394

395

396

397

398

399

400

401

402

403

404

405

406

407

408

409

410

411

Leontarakis PK, and Richardson CA. 2005. Growth of the smooth clam, Callista chione (Linnaeus, 1758) (Bivalvia: Veneridae) from the Thracian Sea, northeastern Mediterranean. Journal of Molluscan Studies 71:189-198.

Lomovasky BJ, Brey T, and Morriconi E. 2005. Population dynamics of the venerid bivalve Tawera gayi (Hupé, 1854) in the Ushuaia Bay, Beagle Channel. Journal of Applied Ichthyology 21:64-69. 10.1111/j.1439-0426.2004.00599.x

MacCord FS, and Amaral ACZ. 2005. Morphometric analyses of two species of Scolelepis (Polychaeta: Spionidae). Journal of the Marine Biological Association of the United Kingdom 85:829-834. 10.1017/S002531540501177X

McKinney RA, Glatt SM, and Williams SR. 2004 Allometric length-weight relationships for benthic prey of aquatic wildlife in coastal marine habitats. Wildlife Biology 10:241-249.

Narchi W. 1972. Comparative study of the functional morphology of Anomalocardia brasiliana (Gmelin, 1791) and Tivela mactroides (Born, 1778) (Bivalvia, Veneridae). Bulletin of Marine Science 22:643-670.

Protopapas NK, S.; Thessalou-Legaki, M.; Verriopoulos, G. 2007. Relative growth of the semiterrestrial crab Pachygrapsus marmoratus: An information-theory approach. Scientia Marina 71:383-394.

Rabaoui L, Tlig Zouari S, Katsanevakis S, and Ben Hassine OK. 2007. Comparison of absolute and relative growth patterns among five Pinna nobilis populations along the Tunisian coastline: an information theory approach. Marine Biology 152:537-548. 10.1007/s00227-007-0707-z

Rainer SF. 1985. Population dynamics and production of the bivalve Abra alba and implications for fisheries production. Marine Biology 85:253-262. 10.1007/bf00393245

Resgalla Jr., Charrid, Brasil, Elisângela de Souza, \& Salomão, Luis Carlos. (2007). The effect of temperature and salinity on the physiological rates of the mussel Perna perna (Linnaeus 1758). Brazilian Archives of Biology and Technology, 50(3), 543-556.

Rhoads DC, and Pannella G. 1970.T the use of molluscan shell growth patterns in ecology and paleoecology. Lethaia 3:143-161. 10.1111/j.1502-3931.1970.tb01854.x

Robinson LA, Greenstreet SPR, Reiss H, Callaway R, Craeymeersch J, de Boois I, Degraer S, Ehrich S, Fraser HM, Goffin A, Kröncke I, Jorgenson LL, Robertson MR, and Lancaster J. 2010. Length-weight relationships of 216 North Sea benthic invertebrates and fish. Journal of the Marine Biological Association of the United Kingdom 90:95-104. 10.1017/S0025315409991408

Statzner B, and Holm TF. 1982. Morphological adaptations of benthic invertebrates to stream flow - An old question studied by means of a new technique (Laser Doppler Anemometry). Oecologia 53:290-292. 10.1007/bf00389001

Trueman ER. 1967. The dynamics of burrowing in Ensis (Bivalvia). Proceedings of the Royal Society of London Series B Biological Sciences 166:459-476.

Turra A, Fernandez WS, Bessa E, Santos FB, and Denadai MR. 2015a. Multi-species generalist predation on the stochastic harvested clam Tivela mactroides (Mollusca, Bivalvia). Estuarine, Coastal and Shelf Science 166:115-123. https://doi.org/10.1016/j.ecss.2014.12.029

Turra A, Petracco M, Amaral ACZ, and Denadai MR. 2014. Temporal variation in life-history traits of the clam Tivela mactroides (Bivalvia: Veneridae): Density-dependent processes in sandy beaches. Estuarine Coastal and Shelf Science 150:157-164. 10.1016/j.ecss.2013.06.004 
412 Turra A, Petracco M, Amaral ACZ, and Denadai MR. 2015b. Population biology and secondary 413 production of the harvested clam Tivela mactroides (Born, 1778) (Bivalvia, Veneridae) in Southeastern Brazil. Marine Ecology-an Evolutionary Perspective 36:221-234.

416

417 10.1111/maec. 12137

Turra A, Xavier LY, Pombo M, de Carvalho Paschoal C, and Denadai MR. 2016. Assessment of recreational harvesting of the trigonal clam Tivela mactroides: Socioeconomic aspects and environmental perception. Fisheries Research 174:58-67. https://doi.org/10.1016/j.fishres.2015.08.026

Trussell, G. C. 2000. Predator-induced plasticity and morphological trade-offs in latitudinallyseparated populations of Littorina obtusata. Evolutionary Ecology Research 2: 803-822.

Urban HJ. 1994. Adaptation of six infaunal bivalve species of Chile: coexistence resulting from differences in morphology, burrowing depth and substrate preference. Archive of fishery and marine research 42:183-193.

Urban HJ, and Campos B. 1994. Population-dynamics of the bivalves Gari solida, Semele solida and Protothaca thaca from a small bay in chile at 36-degrees-S. Marine Ecology Progress Series 115:93-102.

Xiao B, Li E, Du Z, Jiang R, Chen L, Yu N. Effects of temperature and salinity on metabolic rate of the Asiatic clam Corbicula fluminea (Müller, 1774). SpringerPlus. 2014;3:455. doi:10.1186/2193-1801-3-455.

Vasconcelos P, Lopes B, Castro M, and Gaspar MB. 2008. Comparison of indices for the assessment of reproductive activity in Hexaplex trunculus (Gastropoda: Muricidae). Marine Biology Research 4:392-399. 10.1080/17451000802020436

Vasconcelos P, Moura P, Pereira F, Pereira AM, and Gaspar MB. 2018. Morphometric relationships and relative growth of 20 uncommon bivalve species from the Algarve coast (southern Portugal). Journal of the Marine Biological Association of the United Kingdom:98(3):463-474. https://doi.org/10.1017/S002531541600165X 


\section{Table $\mathbf{1}$ (on next page)}

Models and their respective equations and number of parameters estimated plus one ( $k$ ). All models consider origin $=0$. 
1 Table 1. Models and their respective equations and number of parameters estimated plus one $(k)$.

2 All models consider origin $=0$.

\begin{tabular}{lll}
\hline Model & Equation & $\boldsymbol{k}$ \\
\hline Simple regression $(L n)$ & $y=b x$ & 2 \\
Second-order polynomial $(Q d)$ & $y=b x+c x^{2}$ & 3 \\
Third-order polynomial $(C b)$ & $y=b x+c x^{2}+d x^{3}$ & 4 \\
Fourth-order polynomial $(Q t)$ & $y=b x+c x^{2}+d x^{3}+e x^{4}$ & 5 \\
Power-function $(P f)$ & $y=a x^{b}$ & 3 \\
\hline
\end{tabular}

3 


\section{Table 2 (on next page)}

\section{Tivela mactroides.}

Summary and comparison among the determination coefficient $\left(r^{2}\right)$, standard error of the estimate (SE), residual sum of squares (RSS), Akaike information criteria corrected for small samples $\left(A I C_{c}\right)$, and difference between $A I C C(\Delta i)$ of all models.

$L$, shell length; $W$, shell width; $H$, shell height; SW, shell weight; $D W$, soft parts dry weight; AFDW, ash-free dry weight. Ln, linear model; Qd, second-order polynomial model; Cub, third-order polynomial model; Qt, fourth-order polynomial model; Pf, power function. Most suitable model according to AICc and parsimony principle are highlighted in bold. When $\Delta_{i}<2$, the model with the smallest number of parameters was selected. 
1 Table 2. Tivela mactroides. Summary and comparison among the determination coefficient $\left(\mathrm{r}^{2}\right)$, standard 2 error of the estimate (SE), residual sum of squares (RSS), Akaike information criteria corrected for small 3 samples $\left(A I C_{c}\right)$, and difference between $A I C c(\Delta i)$ of all models. L, shell length; W, shell width; $\mathrm{H}$, shell 4 height; SW, shell weight; DW, soft parts dry weight; AFDW, ash-free dry weight. Ln, linear model; Qd, 5 second-order polynomial model; Cub, third-order polynomial model; Qt, fourth-order polynomial model; $6 \mathrm{Pf}$, power function. Most suitable models according to AICc and parsimony principle are highlighted in 7 bold. When $\Delta_{i}<2$, the model with the smallest number of parameters was selected.

8

\begin{tabular}{|c|c|c|c|c|c|c|}
\hline Relation & Model & $\mathbf{r}^{2}$ & SE & RSS & $A I C c$ & $\Delta i$ \\
\hline \multirow[t]{5}{*}{$L / W$} & $L n$ & 0.997 & 0.857 & 136.871 & 476.392 & 94.070 \\
\hline & $Q d$ & 0.998 & 0.753 & 104.985 & 428.861 & 46.539 \\
\hline & $C u b$ & 0.998 & 0.689 & 87.519 & 396.923 & 14.602 \\
\hline & $Q t$ & 0.998 & 0.661 & 80.037 & 382.322 & 0.000 \\
\hline & $P f$ & 0.985 & 0.799 & 118.223 & 451.068 & 68.747 \\
\hline \multirow[t]{5}{*}{$L / H$} & $L n$ & 0.999 & 0.730 & 99.106 & 416.019 & 107.264 \\
\hline & $Q d$ & 0.999 & 0.574 & 61.111 & 327.669 & 18.914 \\
\hline & $C u b$ & 0.999 & 0.546 & 55.005 & 310.073 & 1.318 \\
\hline & $Q t$ & 0.999 & 0.543 & 54.005 & 308.755 & 0.000 \\
\hline & $P f$ & 0.996 & 0.617 & 70.424 & 354.194 & 45.439 \\
\hline \multirow[t]{5}{*}{$L / S W$} & Ln & 0.861 & 1.730 & 556.922 & 738.824 & 464.003 \\
\hline & $Q d$ & 0.987 & 0.530 & 52.115 & 297.891 & 23.070 \\
\hline & $C u b$ & 0.989 & 0.499 & 45.964 & 276.496 & 1.675 \\
\hline & $Q t$ & 0.989 & 0.501 & 45.942 & 278.516 & 3.695 \\
\hline & $P f$ & 0.976 & 0.499 & 46.066 & 274.821 & 0.000 \\
\hline \multirow[t]{5}{*}{$L / D W$} & Ln & 0.844 & 0.094 & 1.637 & -342.574 & 250.325 \\
\hline & $Q d$ & 0.959 & 0.048 & 0.429 & -586.848 & 6.052 \\
\hline & $C u b$ & 0.960 & 0.047 & 0.415 & -591.088 & 1.811 \\
\hline & $Q t$ & 0.961 & 0.047 & 0.411 & -590.689 & 2.210 \\
\hline & $P f$ & 0.918 & 0.047 & 0.415 & -592.899 & 0.000 \\
\hline \multirow[t]{5}{*}{$L / A F D W$} & Ln & 0.842 & 0.086 & 1.351 & -374.856 & 251.689 \\
\hline & $Q d$ & 0.959 & 0.044 & 0.351 & -619.540 & 7.004 \\
\hline & $C u b$ & 0.961 & 0.043 & 0.337 & -624.709 & 1.836 \\
\hline & $Q t$ & 0.961 & 0.043 & 0.334 & -624.112 & 2.433 \\
\hline & $P f$ & 0.918 & 0.043 & 0.338 & -626.544 & 0.000 \\
\hline \multirow[t]{5}{*}{$W / H$} & Ln & 0.999 & 0.835 & 62.982 & 331.243 & 20.198 \\
\hline & $Q d$ & 0.999 & 0.837 & 61.612 & 329.198 & 18.153 \\
\hline & $C u b$ & 0.999 & 0.830 & 55.291 & 311.045 & 0.000 \\
\hline & $Q t$ & 0.999 & 0.7651 & 107.127 & 436.837 & 125.792 \\
\hline & $P f$ & 0.992 & 0.8365 & 129.446 & 468.027 & 156.982 \\
\hline \multirow[t]{5}{*}{$D W / S W$} & Ln & 0.962 & 0.047 & 0.399 & -597.694 & 0.266 \\
\hline & $Q d$ & 0.962 & 0.047 & 0.395 & -597.676 & 0.285 \\
\hline & $C u b$ & 0.963 & 0.046 & 0.393 & -596.381 & 1.580 \\
\hline & $Q t$ & 0.963 & 0.047 & 0.391 & -595.099 & 2.861 \\
\hline & $P f$ & 0.928 & 0.047 & 0.394 & -597.961 & 0.000 \\
\hline \multirow[t]{5}{*}{$D W / A F D W$} & Ln & 0.999 & 0.005 & 0.004 & -1432.479 & 5.734 \\
\hline & $Q d$ & 0.999 & 0.005 & 0.004 & -1434.282 & 3.932 \\
\hline & $C u b$ & 0.999 & 0.005 & 0.004 & -1438.214 & 0.000 \\
\hline & $Q t$ & 0.999 & 0.005 & 0.004 & -1436.168 & 2.045 \\
\hline & $P f$ & 0.999 & 0.005 & 0.004 & -1437.069 & 1.145 \\
\hline
\end{tabular}


Figure 1

Map of the Caraguatatuba Bay, southeastern Brazil. Sampling areas are highlighted in grey.

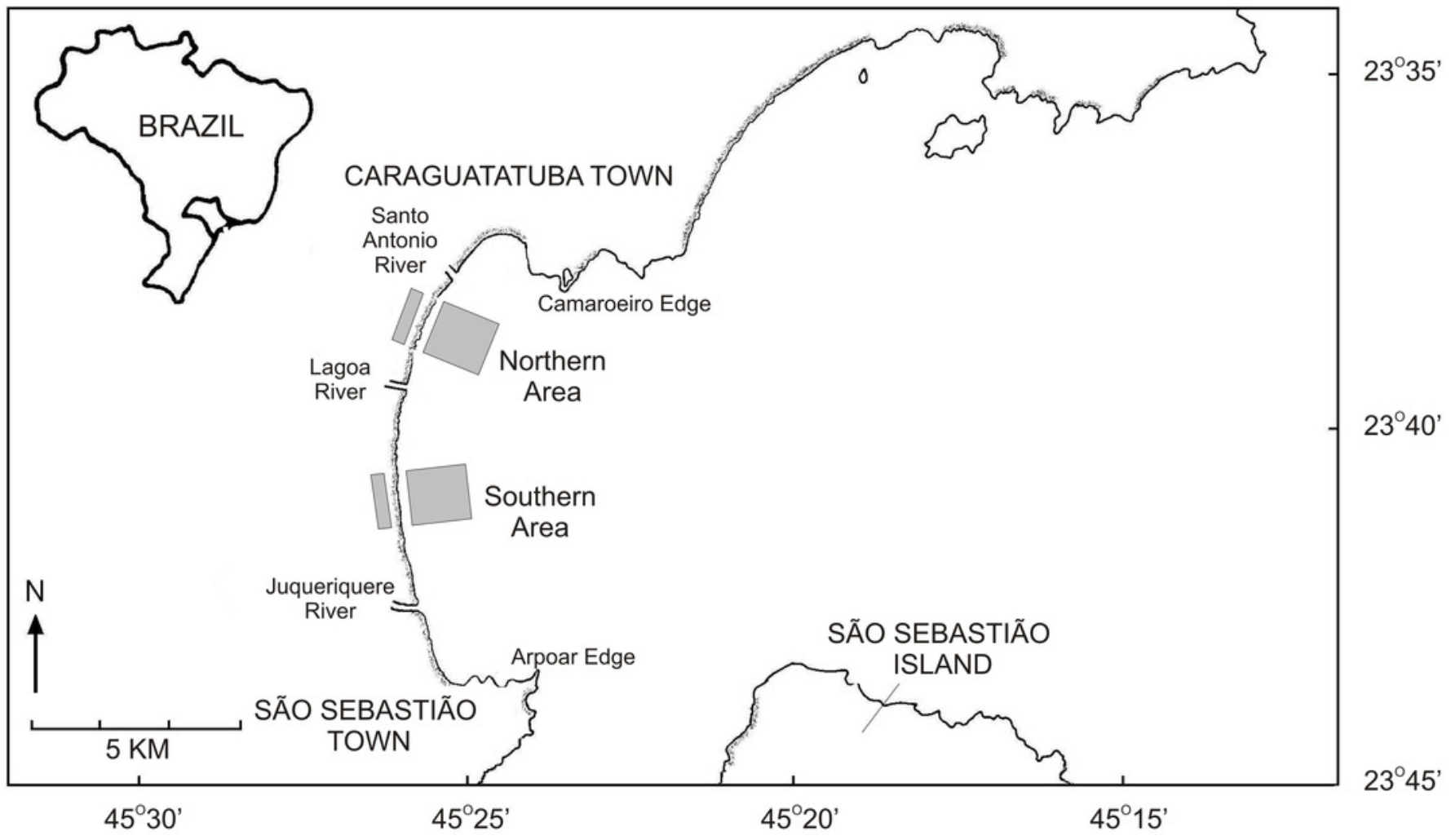


Figure 2

Tivela mactroides. Scheme indicating the measurements taken from the shells (shell length, $\mathrm{L}$; height, $\mathrm{H}$; and width, $\mathrm{W}$ ). (A) frontal view. (B) lateral view.

\section{Tivela mactroides}

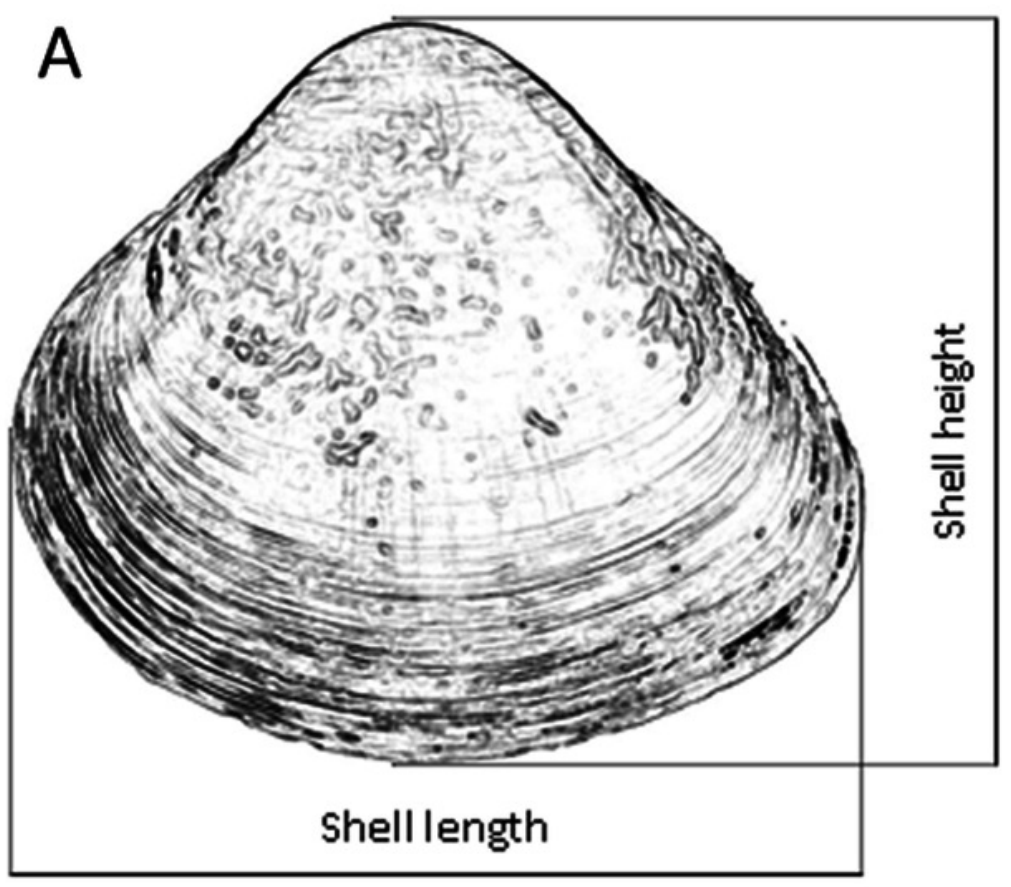

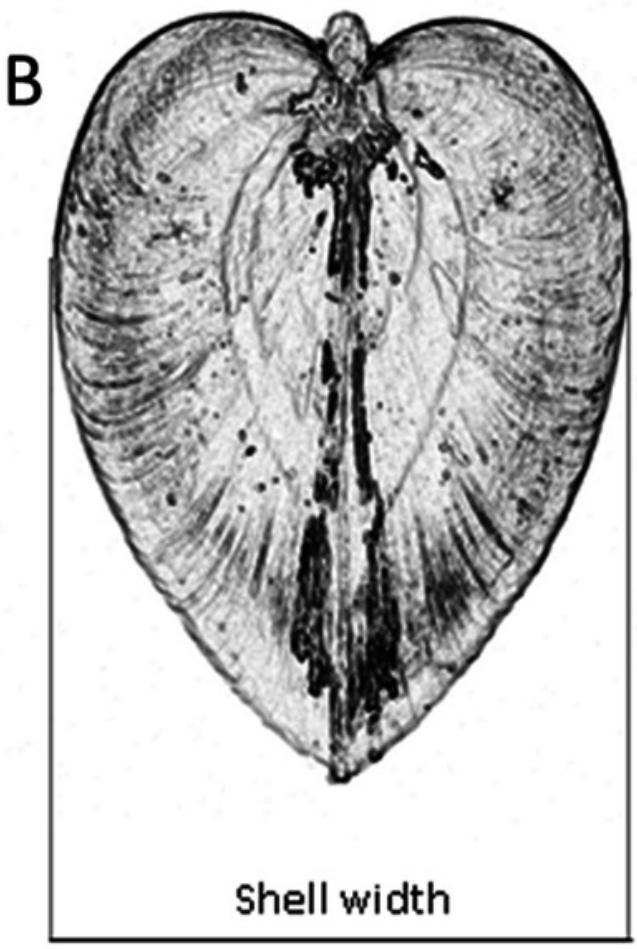




\section{Figure 3}

Tivela mactroides. Graphical representations of the allometric relationships.

Continuous lines represent the most suitable model describing the morphometric relationship. N: number of individuals analyzed. SE: standard error. AFDW: ash-free dry weight. (A) shell width $\sim$ shell length. (B) shell height $\sim$ shell length. (C) shell weigth $\sim$ shell length. (D) dry weigth shell length. (E) ash free dry weigth shell length. (F) shell heigth shell width. (G) dry weigth $\sim$ shell weigth. $(H)$ ash free dry weigth $\sim$ dry weigth. 

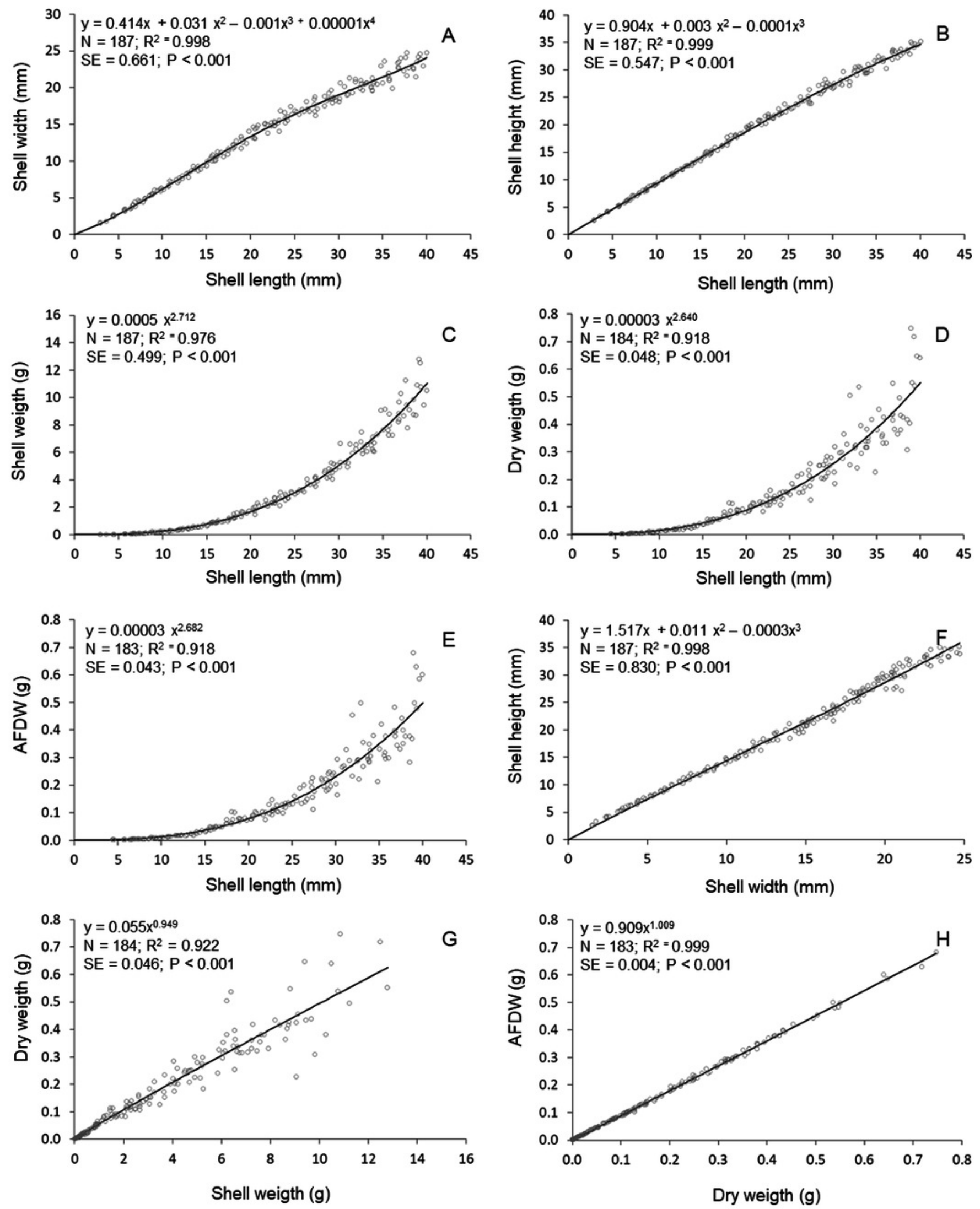